EISSN: 2706-7939 ISSN: 2077-4508

DOI: $10.36632 / \mathrm{ije} / 2021.10 .1 .3$

Journal homepage: www.curresweb.com

Pages: 25-32

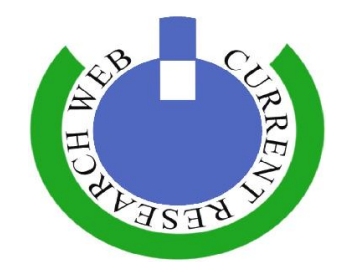

\title{
Effect of Spraying Some Amino Acids, Vitamin B and Boron on Yield and Berry Quality of Superior Grapevines
}

\section{Farouk H. Abdelaziz ${ }^{1}$, Faissal F. Ahmed ${ }^{1}$, Ahmed M.K. Abdel Aal ${ }^{1,2}$, Alaa A.B. Masoud ${ }^{3}$ and Safwat-Manar M. ${ }^{1}$}

${ }^{1}$ Hort. Dept. Fac. of Agric. Minia Univ., Egypt.

${ }^{2}$ Faculty of Meteorology, Environment and Arid Land Agriculture, King Abdulaziz University, Jeddah, Saudi Arabia

${ }^{3}$ Pomology Dept. Fac. of Agric. Assiut Univ., Egypt

Received: 25 December 2020 Accepted: 20 January $2021 \quad$ Published: 10 February 2021

\begin{abstract}
The effect of single and combined application of one of the three amino acids namely (glutamic, glycine and aspartic acid) at $250 \mathrm{ppm}$ from each, vitamin $\mathrm{B}$ complex $\left(\mathrm{B}_{1}+\mathrm{B}_{2}+\mathrm{B}_{6}+\mathrm{B}_{12}\right)$ at $100 \mathrm{ppm}$ and boric acid at $0.05 \%$ on yield and berry quality of Superior grape cultivar were investigated during 2017 and 2018 seasons. Results showed that, single and combined applications of one of three amino acids as well as vitamin B complex and boric acid were very effective on improving yield per vine, bunch characteristics, shot berries \% berry quality of Superior grapevines comparing with untreated vines.

The application of amino acids was more effective than the application of vitamin B and boric acid in this respect. The best results gave which the heaves it yield and best berry quality of Superior grapevines were treating the vines three times (at growth start, just after berry setting and one month later) with a mixture containing $250 \mathrm{ppm}$ glutamic acid plus $100 \mathrm{ppm}$ vitamin B complex and $0.05 \%$ boric acid.
\end{abstract}

Keywords: Superior grapevine yield, berry quality, glutamic acid, glycine, aspartic acid, vitamin B complex, boric acid.

\section{Introduction}

The declines of yield and cluster shot berries in Superior grape cultivar are the major problems facing such grape cultivar production and marketing.

Amino acids with have antioxidative properties play an important role in plant defense against oxidative stress under unfavorable conditions. As well as, enhancing protein biosynthesis, protecting plant cells from senescence and preventing the free radicals from plasma membrane lipids oxidation (Orth et al., 1993). Moreover, they stimulate natural hormone biosynthesis like. IAA, cytokinins, ethylene and $\mathrm{GA}_{3}$. These positive effects surely reflected on producing healthy trees, improved yield and fruit quality. (Vianello and Marci, 1991; Elade, 1992, Ahmed and Abd El- Hameed, 2003; Ahmed et al., 2007; Amin, 2007; Seleem- Basma and Abd El- Hameed, 2008; Sayed- Heba, 2010; Ahmed et al., 2011 and Mohamed 2014a). The previous studies showed that using vitamins was very effective on promoting yield and fruit quality of various grape cultivars (Madian and Refaai 2011; Ibrahim- Rehab, 2012; Abdelaal, 2012; Ahmed et al., 2012; Abada, and Basma 2015; Abd El- Latief, 2014 and AlWasfy, 2014).

It was found that, boron spraying is an effective method to improve reproductive and vegetative tissues, where the reproductive tissues of grapevines are the most sensitive parts to boron deficiency, which lead to reduce fruit set and causing negative effects on fruit yield. On the other side, the over dose of boron can lead to plant phytotoxicity (Christensen and Smart, 2005; Amin, 2007; Ahmed et al.,

Corresponding Author: Farouk H. Abdelaziz, 1Hort. Dept. Fac. of Agric. Minia Univ., Egypt. 
2007; Abd El- Gaber- Nermean, 2009; El- Sawy, 2009; Abd El- Wahab, 2010; El- Kady- Hanaa , 2011; Abdelaal, 2012; Nikkah et al., 2013 and Mohamed, 2014b).

The dim of this study was to examine the effect of single and combined applications of some amino acids (glutamic acid, glycine and aspartic acid), vitamin $\mathrm{B}$ complex $\left(\mathrm{B}_{1}+\mathrm{B}_{2}+\mathrm{B}_{6}+\mathrm{B}_{12}\right)$ and boric acid on yield and berry quality of Superior grape cultivar.

\section{Materials and Methods}

This study was carried out during 2017 and 2018 seasons on 90 uniform 6 years old Superior grapevines grown at a private vineyard located at Talla village, Minia district, Minia Governorate where the texture of the soil is clay, well drained and water table not less than two meters deep.

All the selected vines are planted at $1.5 \times 3.0$ meters apart. The chosen vines ( 90 vines) were pruned during the last week of December during the both seasons of study using cane pruning method with the assistance of Gable supporting system. Bud load per vine was 96 eyes for all the selected vines on the basis of eight fruiting cans $\mathrm{x}$ ten eyes plus eight renewal spurs $\mathrm{x}$ two eyes. Except those vines dealing with the present treatments, (application of amino acids, vitamin B and boric acid via foliage) all the selected vines (90 vines) received the usual horticultural practices which are commonly used in the vineyard.

This study included fifteen treatments containing single or combined application of three amino acids (i.e., glutamic acid, glycine and aspartic acid), vitamin $\mathrm{B}$ complex $\left(\mathrm{B}_{1}+\mathrm{B}_{2}+\mathrm{B}_{6}+\mathrm{B}_{12}\right)$ and boron acid in additions to the untreated vines (control).

1- Untreated vines (Control).

2- Spraying with $250 \mathrm{ppm}$ glutamic acid.

3- Spraying with $250 \mathrm{ppm}$ glycine.

4- $\quad$ Spraying with $250 \mathrm{ppm}$ aspartic acid.

5- Spraying with $100 \mathrm{ppm}$ vitamin $\mathrm{B}\left(\mathrm{B}_{1}+\mathrm{B}_{2}+\mathrm{B}_{6}+\mathrm{B}_{12}\right)$.

6- Spraying with $0.05 \%$ boric acid.

7- Spraying a mixture of $250 \mathrm{ppm}$ glutamic acid $+100 \mathrm{ppm}$ vitamin B complex.

8- $\quad$ Spraying a mixture of $250 \mathrm{ppm}$ glycine $+100 \mathrm{ppm}$ vitamin $\mathrm{B}$ complex.

9- Spraying a mixture of $250 \mathrm{ppm}$ aspartic acid $+100 \mathrm{ppm}$ vitamin B complex.

10 - Spraying a mixture of $250 \mathrm{ppm}$ glutamic acid $+0.05 \%$ Boric acid.

11- Spraying a mixture of $250 \mathrm{ppm}$ glycine $+0.05 \%$ Boric acid.

12- Spraying a mixture of $250 \mathrm{ppm}$ aspartic acid $+0.05 \%$ Boric acid.

13- Spraying a mixture of $250 \mathrm{ppm}$ glutamic acid $+100 \mathrm{ppm}$ vitamin B complex $+0.05 \%$ Boric acid.

14- Spraying a mixture of $250 \mathrm{ppm}$ glycine acid $+100 \mathrm{ppm}$ vitamin B complex $+0.05 \%$ Boric acid.

15- Spraying a mixture of $250 \mathrm{ppm}$ aspartic acid $+100 \mathrm{ppm}$ vitamin B complex $+0.05 \%$ Boric acid.

The experiment was designed as a complete randomized block (Rangaswamy, 1995) where the experiment consisted of fifteen treatments and each treatment was replicated on 6 vines.

The selected vines sprayed three times during the growing season. The $1^{\text {st }}$ time at the $1^{\text {st }}$ week of March just after berry setting, the $2^{\text {nd }}$ time during the $1^{\text {st }}$ week of April and the $3^{\text {rd }}$ time was one month later ( $1^{\text {st }}$ week of May).

Triton B as a wetting agent was added to all spraying solutions at $0.05 \%$. Spaying was done till run off ( 2 liters/ vine). Control treatment was carried out by spraying water only.

During both of studies seasons, the following measurements were recorded:

1- Yield weight (kg. / vine), clusters number / vine, as well as weight (g.), length and width of bunch (cm).

2- Shot berries $\%$ by dividing shot berries number by the total berries number of bunch and multiplying the product $\mathrm{x} 100$.

3- Berry weight (g.)

4- Berry dimensions (length and diameter $(\mathrm{cm}$.)

5- Percentage of total soluble solids (TSS \%) in berry juice by using a hand refractometer. 
6- Percentage of titratable acidity (TA \%) (as grams of tartaric acid/ $100 \mathrm{ml}$ juice) by titration of $5 \mathrm{ml}$ berry juice against $0.1 \mathrm{~N} \mathrm{NaOH}$ using phenolphthalein as on indicator (A.O.A.C., 2000), and then TSS/TA ratio in berry juice was calculated.

7- Percentage of reducing sugars in berry juice by Lane and Eynon (1965) Volumetric method as described in A.O.A., 2000). Statistical analysis was done. Treatment means were compared using L.S.D. at 5\% level of the probability (Mead et al., 1993).

\section{Results and Discussion}

1- Effect of single and combined applications of some amino acids, vitamin B and boron on yield and cluster characteristics:

Data presented in Table 1 obviously revealed that yield expressed in weight (kg.) and bunch number per vine, as well as bunch weight $(\mathrm{g})$ and dimensions were significantly improved in response to spraying the treatments compared with the check treatment. The promotion on these parameters was significantly associated with the treatments through a descending order, whereas using amino acids was significantly preferable than using vitamin B and boric acid. Combined applications of one of the three amino acids and vitamin B complex and boric acid was significantly favorable than using each alone in this respect. The best results induced the heaviest yield weight and improved cluster characteristics were spraying a mixture of $250 \mathrm{ppm}$ glutamic acid, $100 \mathrm{ppm}$ vitamin B complex and $0.05 \%$ boric acid compared with the untreated vines which produced the lowest values. The results were true during the two studied seasons.

Table 1: Effect of spraying single and combined applications of some amino acids (glutamic acid, glycine and aspartic acid), vitamin B complex and boric acid on clusters Number per vine, yield weight $(\mathrm{kg})$ and cluster weight and dimensions of Superior grapevines during 2017 and 2018 seasons.

\begin{tabular}{|c|c|c|c|c|c|c|c|c|c|c|}
\hline \multirow[b]{2}{*}{ Treatments } & \multicolumn{5}{|c|}{2017} & \multicolumn{5}{|c|}{2018} \\
\hline & $\begin{array}{c}\text { Clusters } \\
\text { No. / } \\
\text { vine }\end{array}$ & $\begin{array}{c}\text { Yield } \\
\text { weight } \\
\text { (kg. / } \\
\text { vine) }\end{array}$ & $\begin{array}{c}\text { Cluster } \\
\text { weight } \\
\text { (g.) }\end{array}$ & $\begin{array}{c}\text { Cluster } \\
\text { length } \\
\text { (cm.) }\end{array}$ & $\begin{array}{c}\text { Cluster } \\
\text { width } \\
\text { (cm.) }\end{array}$ & $\begin{array}{c}\text { Clusters } \\
\text { No. / } \\
\text { vine }\end{array}$ & $\begin{array}{c}\text { Yield } \\
\text { weight } \\
\text { (kg. / } \\
\text { vine) }\end{array}$ & $\begin{array}{c}\text { Cluster } \\
\text { weight } \\
\text { (g.) }\end{array}$ & $\begin{array}{c}\text { Cluster } \\
\text { length } \\
\text { (cm.) }\end{array}$ & $\begin{array}{c}\begin{array}{c}\text { Cluster } \\
\text { width } \\
(\mathrm{cm} .)\end{array} \\
\text { ( }\end{array}$ \\
\hline 1-Control & 27.0 & 9.5 & 365.0 & 15.5 & 10.5 & 26.0 & 9.6 & 370.0 & 15.8 & 10.7 \\
\hline $\begin{array}{l}\text { 2-Glutamic acid at } 250 \\
\text { ppm }\end{array}$ & 29.0 & 9.9 & 382.5 & 16.7 & 11.7 & 30.0 & 11.5 & 384.0 & 16.9 & 11.8 \\
\hline 3- Glycine at $250 \mathrm{ppm}$ & 30.0 & 9.9 & 380.5 & 16.5 & 11.5 & 29.0 & 11.1 & 383.5 & 16.7 & 11.6 \\
\hline $\begin{array}{l}\text { 4-Aspartic acid at } 250 \\
\text { ppm. }\end{array}$ & 26.0 & 9.8 & 378.5 & 16.3 & 11.3 & 28.0 & 10.6 & 380.0 & 16.4 & 11.5 \\
\hline $\begin{array}{l}\text { 5- Vitamin B at } 100 \\
\text { ppm }\end{array}$ & 26.0 & 9.7 & 375.0 & 16.0 & 11.1 & 27.0 & 10.2 & 378.0 & 16.2 & 11.2 \\
\hline 6- Boric acid at $0.05 \%$ & 27.0 & 9.6 & 372.5 & 15.8 & 10.9 & 26.0 & 9.7 & 375.5 & 16.0 & 11.1 \\
\hline $\begin{array}{l}\text { 7-Glutamic acid + } \\
\text { vitamin B }\end{array}$ & 31.0 & 10.3 & 395.5 & 18.0 & 13.2 & 33.0 & 13.1 & 397.0 & 18.2 & 13.4 \\
\hline 8- Glycine + vitamin B & 26.0 & 10.2 & 393.0 & 17.8 & 12.9 & 33.0 & 13.0 & 395.0 & 18.0 & 13.0 \\
\hline $\begin{array}{l}\text { 9-Aspartic acid + } \\
\text { vitamin B }\end{array}$ & 33.0 & 10.1 & 390.0 & 17.6 & 12.7 & 32.0 & 12.5 & 392.0 & 17.8 & 12.8 \\
\hline $\begin{array}{l}\text { 10-Glutamic acid + } \\
\text { Boric acid }\end{array}$ & 31.0 & 10.1 & 389.5 & 17.6 & 12.7 & 32.0 & 12.5 & 391.0 & 17.8 & 12.8 \\
\hline $\begin{array}{l}\text { 11- Glycine + Boric } \\
\text { acid }\end{array}$ & 26.0 & 10.0 & 388.0 & 17.4 & 12.3 & 31.0 & 12.1 & 390.0 & 17.7 & 12.5 \\
\hline $\begin{array}{l}\text { 12-Aspartic acid + } \\
\text { Boric acid }\end{array}$ & 30.0 & 10.0 & 285.0 & 17.0 & 12.0 & 30.0 & 11.6 & 388.0 & 17.5 & 12.2 \\
\hline $\begin{array}{l}\text { 13-Glutamic acid }+ \\
\text { vitamin } B+\text { Boric acid }\end{array}$ & 34.0 & 10.6 & 406.0 & 19.0 & 13.8 & 34.0 & 13.9 & 408.5 & 19.5 & 13.9 \\
\hline $\begin{array}{l}\text { 14- Glycine + vitamin } \\
\text { B + Boric acid }\end{array}$ & 33.0 & 10.5 & 403.0 & 18.5 & 13.5 & 34.0 & 13.8 & 405.0 & 18.8 & 13.7 \\
\hline $\begin{array}{l}\text { 15-Aspartic acid + } \\
\text { vitamin B + Boric acid }\end{array}$ & 33.0 & 10.4 & 400.0 & 18.2 & 13.1 & 33.0 & 13.3 & 402.5 & 18.5 & 13.3 \\
\hline New L.S.D at 5\% & 1.0 & 0.1 & 4.5 & 0.4 & 0.3 & 1.0 & 0.3 & 4.7 & 0.3 & 0.3 \\
\hline
\end{tabular}


2-Effect of single and combined applications of some amino acids, vitamin B complex and boron on shot berries percentage:

Data found in Table 2 clearly showed that the percentage of shot berries No./bunch was significantly decreased as a result of all the treatments compared with the check treatment. The best effect of amino acids in this respect was spraying glutamic acid, glycine and aspartic acid in descending order. Using amino acids was significantly superior comparing with the rest of treatments.

Table 2: Effect of spraying single and combined applications of some amino acids (glutamic acid, glycine and aspartic acid), vitamin B complex and boric acid on shot berries $\%$ and physical characteristics of berries of Superior grapevines during 2017 and 2018 seasons.

\begin{tabular}{|c|c|c|c|c|c|c|c|c|}
\hline \multirow[b]{2}{*}{ Treatments } & \multicolumn{4}{|c|}{2017} & \multicolumn{4}{|c|}{2018} \\
\hline & $\begin{array}{c}\text { Shot } \\
\text { berries } \\
\%\end{array}$ & $\begin{array}{c}\text { Berry } \\
\text { weight } \\
\text { (g.) }\end{array}$ & $\begin{array}{c}\text { Berry } \\
\text { diameter } \\
\text { (cm) }\end{array}$ & $\begin{array}{l}\text { Berry } \\
\text { length } \\
(\mathrm{cm})\end{array}$ & $\begin{array}{c}\text { Shot } \\
\text { berries } \\
\%\end{array}$ & $\begin{array}{c}\text { Berry } \\
\text { weight } \\
\text { (g.) }\end{array}$ & $\begin{array}{c}\text { Berry } \\
\text { diameter } \\
\text { (cm) }\end{array}$ & $\begin{array}{l}\text { Berry } \\
\text { length } \\
\text { (cm) }\end{array}$ \\
\hline 1-Control & 10.5 & 4.95 & 2.10 & 1.77 & 10.4 & 5.00 & 2.12 & 1.80 \\
\hline 2-Glutamic acid at $250 \mathrm{ppm}$ & 8.8 & 5.28 & 2.22 & 1.90 & 8.6 & 5.30 & 2.24 & 1.91 \\
\hline 3- Glycine at $250 \mathrm{ppm}$ & 9.1 & 5.23 & 2.20 & 1.88 & 9.0 & 5.25 & 2.22 & 1.90 \\
\hline 4-Aspartic acid at $250 \mathrm{ppm}$. & 9.5 & 5.20 & 2.19 & 1.85 & 9.2 & 5.22 & 2.20 & 1.88 \\
\hline 5- Vitamin B at $100 \mathrm{ppm}$ & 9.7 & 5.14 & 2.16 & 1.83 & 9.5 & 5.18 & 2.18 & 1.85 \\
\hline 6- Boric acid at $0.05 \%$ & 10.2 & 5.10 & 2.13 & 1.80 & 10.0 & 5.15 & 2.15 & 1.82 \\
\hline 7-Glutamic acid + vitamin B & 7.1 & 5.67 & 2.40 & 2.03 & 7.0 & 5.70 & 2.42 & 2.05 \\
\hline 8- Glycine + vitamin B & 7.4 & 5.60 & 2.33 & 1.99 & 7.1 & 5.62 & 2.35 & 2.02 \\
\hline 9-Aspartic acid + vitamin B & 7.7 & 5.50 & 2.29 & 1.95 & 7.5 & 5.55 & 2.32 & 1.99 \\
\hline $\begin{array}{l}\text { 10-Glutamic acid }+ \text { Boric } \\
\text { acid }\end{array}$ & 7.7 & 5.50 & 2.29 & 1.95 & 7.5 & 5.55 & 2.32 & 1.98 \\
\hline 11- Glycine + Boric acid & 8.1 & 5.40 & 2.28 & 1.93 & 7.8 & 5.45 & 2.30 & 1.95 \\
\hline 12-Aspartic acid + Boric acid & 8.6 & 5.35 & 2.24 & 1.91 & 8.5 & 5.40 & 2.25 & 1.92 \\
\hline $\begin{array}{l}\text { 13-Glutamic acid + vitamin } \\
\text { B + Boric acid }\end{array}$ & 6.5 & 5.98 & 2.50 & 2.12 & 5.8 & 6.08 & 2.54 & 2.15 \\
\hline $\begin{array}{l}\text { 14- Glycine + vitamin B + } \\
\text { Boric acid }\end{array}$ & 6.8 & 5.85 & 2.45 & 2.09 & 6.2 & 5.90 & 2.48 & 2.11 \\
\hline $\begin{array}{l}\text { 15-Aspartic acid + vitamin B } \\
+ \text { Boric acid }\end{array}$ & 7.0 & 5.70 & 2.41 & 2.05 & 6.8 & 5.75 & 2.45 & 2.08 \\
\hline New L.S.D at 5\% & 0.4 & 0.11 & 0.05 & 0.06 & 0.4 & 0.12 & 0.06 & 0.06 \\
\hline
\end{tabular}

3-Effect of single and combined applications of some amino acids, vitamin B and boron on the quality of berries:

It is evident from the data in Tables 2 and 3 that spraying three amino acids (glutamic acid, glycine and aspartic acid) at $250 \mathrm{ppm}$ each, and $100 \mathrm{ppm}$ vitamin B complex $0.05 \%$ boron acid significantly improved berry quality in terms of increasing berry weight and dimensions (length and diameter), T.S.S. $\%$, reducing sugars $\%$ and T.S.S. / acid ratio and decreasing titratable acidity $\%$ rather than non- application. Using three amino acids namely glutamic acid at $250 \mathrm{ppm}$, glycine at $250 \mathrm{ppm}$ and aspartic acid at $250 \mathrm{ppm}$ in descending order was significantly preferable on enhancing quality of the berries. Using some amino acids was significantly favorable than using vitamin B and boric acid in this connection. The best results as regard to berry quality were obtained due to using glutamic acid at $250 \mathrm{ppm}$, vitamin B complex at $100 \mathrm{ppm}$ and boric acid at $0.05 \%$ together. These results were true during the two seasons. Unfavorable effects were observed in the untreated vines. 
Table 3: Effect of spraying single and combined applications of some amino acids (glutamic acid, glycine and aspartic acid), vitamin B complex and boric acid on berry chemical characteristics of Superior grapevines during 2017 and 2018 seasons.

\begin{tabular}{|c|c|c|c|c|c|c|c|c|}
\hline \multirow[b]{2}{*}{ Treatments } & \multicolumn{4}{|c|}{2017} & \multicolumn{4}{|c|}{2018} \\
\hline & T.S.S.\% & $\begin{array}{c}\text { Reducing } \\
\text { sugars } \\
\%\end{array}$ & $\begin{array}{c}\text { Total } \\
\text { acidity } \\
\%\end{array}$ & $\begin{array}{c}\text { T.S.S. } \\
/ \\
\text { acid. }\end{array}$ & T.S.S.\% & $\begin{array}{c}\text { Reducing } \\
\text { sugars } \\
\%\end{array}$ & $\begin{array}{c}\text { Total } \\
\text { acidity } \\
\%\end{array}$ & $\begin{array}{c}\text { T.S.S. } \\
/ \\
\text { acid. }\end{array}$ \\
\hline 1-Control & 17.8 & 15.3 & 0.704 & 25.2 & 17.9 & 15.4 & 0.710 & 25.2 \\
\hline $\begin{array}{l}\text { 2-Glutamic acid at } 250 \\
\text { ppm }\end{array}$ & 19.0 & 16.6 & 0.665 & 28.5 & 19.2 & 16.8 & 0.660 & 29.1 \\
\hline 3- Glycine at $250 \mathrm{ppm}$ & 18.8 & 16.3 & 0.675 & 27.8 & 19.0 & 16.4 & 0.670 & 28.3 \\
\hline $\begin{array}{l}\text { 4-Aspartic acid at } 250 \\
\text { ppm. }\end{array}$ & 18.5 & 16.0 & 0.680 & 27.2 & 18.8 & 16.2 & 0.675 & 27.8 \\
\hline 5- Vitamin B at 100 ppm & 18.2 & 15.7 & 0.690 & 26.3 & 18.5 & 15.9 & 0.688 & 26.9 \\
\hline 6- Boric acid at $0.05 \%$ & 18.0 & 15.5 & 0.695 & 25.8 & 18.2 & 15.7 & 0.692 & 26.3 \\
\hline $\begin{array}{l}\text { 7-Glutamic acid + vitamin } \\
\text { B }\end{array}$ & 20.5 & 18.1 & 0.620 & 33.0 & 20.8 & 18.3 & 0.615 & 33.8 \\
\hline 8- Glycine + vitamin B & 20.0 & 17.7 & 0.630 & 31.7 & 20.5 & 17.9 & 0.625 & 32.8 \\
\hline $\begin{array}{l}\text { 9-Aspartic acid + vitamin } \\
\text { B }\end{array}$ & 19.8 & 17.5 & 0.642 & 30.8 & 20.0 & 17.7 & 0.635 & 31.5 \\
\hline $\begin{array}{l}\text { 10-Glutamic acid + Boric } \\
\text { acid }\end{array}$ & 19.8 & 17.4 & 0.645 & 30.7 & 20.0 & 17.7 & 0.638 & 31.3 \\
\hline 11- Glycine + Boric acid & 19.5 & 17.0 & 0.650 & 30.0 & 19.8 & 17.3 & 0.640 & 30.9 \\
\hline $\begin{array}{l}\text { 12-Aspartic acid + Boric } \\
\text { acid }\end{array}$ & 19.2 & 16.8 & 0.660 & 29.1 & 19.5 & 17.0 & 0.650 & 30.0 \\
\hline $\begin{array}{l}\text { 13-Glutamic acid } \\
\text { vitamin B }+ \text { Boric acid }\end{array}$ & 21.2 & 18.7 & 0.590 & 35.9 & 21.5 & 18.9 & 0.588 & 36.5 \\
\hline $\begin{array}{l}\text { 14- Glycine + vitamin B + } \\
\text { Boric acid }\end{array}$ & 21.0 & 18.5 & 0.595 & 35.2 & 21.2 & 18.7 & 0.590 & 35.9 \\
\hline $\begin{array}{l}\text { 15-Aspartic acid }+ \\
\text { vitamin B }+ \text { Boric acid }\end{array}$ & 20.6 & 18.2 & 0.610 & 33.8 & 21.0 & 18.5 & 0.605 & 34.7 \\
\hline New L.S.D at 5\% & 0.3 & 0.3 & 0.011 & 1.1 & 0.4 & 0.4 & 0.012 & 1.3 \\
\hline
\end{tabular}

\section{Discussion}

\section{1-Effect of amino acids:}

Amino acids as organic nitrogenous compounds are the building blocks in the synthesis of proteins, which are formed by as process in which ribosome's catalyze the polymerization of amino acids (Davies, 1982 and Raskin, 1992). Several hypothesis have been proposed the explain for the role of amino acids in plant. Available evidence suggests several alternative routes of IAA and ethylene synthesis in plants, starting from amino acids (Hashimoto and Yamada, 1994). These results are in concordance with those obtained by (Abdelaal, et al., 2013; Gad El- Kareem and Abada, 2014; Mohamed, 2014a and El- Khawaga, 2014).

\section{2-Effect of vitamin B:}

Vitamin B is responsible for enhancing amino acids biosynthesis, carbohydrates, plant pigments and cell division (Samiullah et al., 1988). The same authors disclosed that vitamin B are responsible for enhancing uptake of water and nutrient and increasing the tolerance of plant to all stresses.

These results regarding the effect of antioxidants are in agreement with those obtained by El-KadyHanaa, (2011); Madian and Refaai, (2011); Uwakiem, (2011); Abd El- Hameed, (2012); Abdelaal, (2012) and Ibrahiem- Rehab (2012).

\section{3-Effect of Boron:}

Boron plays an important role in the extension of plant cell walls through its association with cell wall pectins (Banik and Sen, 1997 and Perica et al., 2001). It is also known that the role of boron in plant metabolism including many physiological aspects such as nucleic acid metabolism, protein and natural hormone biosynthesis, building and translocation of carbohydrates photosynthesis, cell division, cell wall synthesis membrane function, water uptake and pollen germination (Pilbeam and Kirkby, 1983; Gupta et al., 1985; Belvins and Lukaszweski, 1998). 
These results regarding the promotion effect of boron growth, vine nutritional status, yield and quality are in agreement with those obtained by Ali, (2000) and Abd El- Hady (1995) on Flame seedless grapevines, Ahmed et al., (2003) and Abd El- Hameed, (2012); Ahmed et al., (2007) ; Amin, (2007) and Abd El- Gaber- Nermean (2009) on Red Roomy grapevines, El Sawy, (2009) on Superior grapevines , Farahat (2008) on Red Globe grapevines as well as El- Kady, Hanaa(2011), and Abdelaal (2012) on Thompson Seedless grapevines.

\section{Conclusion}

The best results with regard to yield and berries quality of Superior grapevines were obtained by spraying the vines three times with a mixture of glutamic acid at $250 \mathrm{ppm}, 100 \mathrm{ppm}$ vitamin B complex and $0.05 \%$ boric acid.

\section{References}

Abada, M.A.M. and R. Ahmed- Basma, 2015. The beneficial effects of using Royal Jelly, Arginine and Tryptophane on fruiting of Superior grapevines. Egypt. J. Hort. Vol. 421, pp. 347-356.

Abd El- Hady, A.M., 1995. Response of Roomy Red grapevines to foliar sprays of urea and boron. Ph. D. Thesis Fac. of Agric. Minia Univ. Egypt.

Abd El- Hameed, H.M., 2012. Using silicon, Boron and folic acid to promote yield quantitatively and qualitatively of early Superior grapevines. Minia J. of Agric. Res. \& Develop., 32(5) 869-886.

Abd El- Latief, M.M.H., 2014. Response of Thompson seedless grapevines of Thompson seedless grapevines to spraying of some vitamin. M. Sc. Thesis Fac. of Agric. El- Azhar Univ. Assiut Branch, Egypt.

Abd El- Wahab, M.H., 2010. Relation of fruiting in Superior grapevines with spraying sulphur, magnesium, zinc and boron. M. Sc. Thesis. Fac. of Agric. Minia Univ. Egypt.

Abd El-Gaber- Nermean, M.E.H., 2009. Response of Red Roomy grapevines to foliar application of boron, magnesium and zinc. M. Sc. Thesis Fac. of Agric. Minia Univ. Egypt.

Abdelaal, A.M.K., F.F. Ahmed and E.E.H. Abdelaal, 2013. The stimulative effects of using some nutrients and antioxidants on growth, nutritional status and yield of Thompson seedless grapes. Hort. Science J. of Suez Canal Univ. 1: 322-329.

Abdelaal, E.E.H.A., 2012. The Synergistic effects of using some nutrients as well as antioxidant substances on growth, nutritional status and productivity of Thompson seedless grapevines grown under Sohag region. Ph. D. Thesis Fac. of Agric. Sohag Univ. Egypt.

Ahmed, A. H. and H. M. Abd El- Hameed, 2003. Growth, uptake of some nutrients and productivity of Red Roomy vines as affected by spraying of some amino acids, magnesium and boron. Minia J. of Agric. Res. \& Develop., 723 (4): 649 - 666.

Ahmed, F. F., A. M. K. Abdel- aal, F. H. Abdelaziz and F. M. EI- Kady- Hanaa, 2011. Productive capacity of Thompson seedless grapevines as influenced by application of some antioxidants and nutrient treatments. Minia J. of Agric. Res. \& Develop., 31(2): 219-232.

Ahmed, F.F., M.A. Mohamed, A.M.K. Abd El-Aal and M.M. Amin, 2007. Response of Red Roomy grapevine to application of amino acids and some micronutrients. The Third Conference for Sustainable Agricultural Development, Al-Fayoum, 12-14 November pp,150-170.

Al- Wasfy, M.M.M., 2014. The synergistic effects of using silicon with some vitamin on growth and fruiting of Flame seedless grapevines. Stem Cell 5( 1): 8-13.

Ali, A.H., 2000. Response of Flame seedless grapevines to spraying with ascorbic acid and boron. Minia J. of Agric. Res. \& Develop, 20(1): 159-174.

Amin, M. M. A., 2007. Response of Red Roomy grapevines to application of amino acids and some micronutrients. M. Sc. Thesis Fac. of Agric. Minia Univ. Egypt.

Association of Official Agricultural Chemists, 2000. Official Methods of Analysis (A.O.A.C), $12^{\text {th }}$ Ed. Benjamin Franklin Station, Washington D.C. (U.S.A.) pp. 490-510

Blevins, D.G. and M.K. Lukaszweski, 1998. Boron in plant structure and function. Annual Plant Physio. Plant. Mol. Biol. 489-481

Christensen, P.L. and D.R. Smart, 2005. Foliar fertilization in vine mineral nutrient management programs. Proc. of the soil environment and vine mineral nutrition Sym. San. Diegu, California, 
USA, 29-3 Junes, pp. 10-20.

Davies, D.D., 1982. Physiological aspects of protein turmour Encyclo. Plant Physiol. 13 A, Eds Boulter, D. and B Partier Soringer verlag, Berlin, New York, pp. 190- 228.

El- Sawy, Y.A.E., 2009. Attempts for breaking dormancy and improving fruiting of Superior grapevines. Ph. D. Thesis Fac. of Agric. Minia Univ. Egypt.

Elade, Y., 1992. The use of antioxidants to control gray mould (Botrytic cinerg) and white mould (Scletotinia sclerotiorum) in various crops plant pathol. 141: 417-426.

El-Kady-Hanaa, F. M., 2011. Productive performance of Thompson seedless grapevines in relation to application of some antioxidants, magnesium and boron. M. Sc. Thesis Fac. of Agric. Minia Univ. Egypt.

El-Khawaga, A.S., 2014. Impact of vitamin B and C, glutamic acid and silicon on fruiting of Superior grapevines. World Rural Observations. 6(4): 57-62.

Gad El- Kareem, M.R. and M.A.M. Abada, 2014. Trials for promoting productivity of Flame seedless grapevines. J. of Biol. Chem. Environ. Sci., 9(1): 35-40.

Gupta, M.C., Y.W. Hama, C.A. Campbell, A.J. Leyshon, and V. Nicholoichnk, 1985. Boron toxicity and deficiency Canadian J. Soil Sci., 65:381-409.

Hashimoto, T. and Y. Yamada, 1994. Alkaloid biosynthesis Molecular aspects Ann. Res. Plant Physio. Plant. Md. Bio. Pp. 243-257.

Ibrahim- Rehab, G., 2012. Behaviour of Thompson seedless grapevines to spraying of some vitamin. M. Sc. Thesis Fac. of Agric. Minia Univ. Egypt.

Lane, J. H. and L. Eynon, 1965. Determination of reducing sugars by means of Fehlings solution with methyiene blue as indicator. A.O.A.C Washington D.C. U.S.A..

Madian, A.M. and M.M. Refaai, 2011. The synergistic effects of using B vitamin with the two amino acids tryptophane and methionene in Thompson seedless grapevines. Minia J. of Agric. Res. \& Develop. Vol. (31): No.3, pp. 445-454.

Mead, R., R.N. Currnow and A.M. Harted, 1993. Statistical Methods in Agricultural and Experimental Biology. Second Ed. Chapman \& Hall, London, pp. 54-60.

Mohamed, T.M.M., 2014a. Relation of fruiting in Superior grapevines with spraying salicylic acids and boron . M. Sc. Thesis Fac. of Agric. Minia Univ. Egypt.

Mohamed, W.B.M., 2014b. Effect of some amino acid, nutrients and salicylic acid treatments on Superior grapevines, cultivar. M. Sc. Thesis Fac. of Agric. E1- Azhar Univ. Assiut Branch, Egypt.

Nikkhah, R., H. Nafar, S. Rastgoo and M. Dorostkar, 2013. Effect of foliar application of boron and zinc on qualitative and quantitative fruit characteristics of grapevines (Vitis vinifera L.) Intl $\mathrm{J}$. Agric. Crop sci., 6 (9): 485-192.

Orth, A.B., A. Sfarra, R.J. Pell, and M. Tlen, 1993. Assessing the involvement of free radicals in fungicide toxicity using X-tocopherol analogs pesticide. Biochemistry and physiology, 47: 134141.

Peacock, W.L. and L.P. Christensen, 2005. Drip Irrigation can effectively apply boron to San Joaquin Valley vineyard Calif Agric. 59: 188-191.

Pilbeam, D.J. and E.A. Kirkby, 1983. The physiological role of boron in plants. J. Plant Nutrition 6 : 563-582.

Rangaswamy, R., 1995. Randomized Complete Block Design. In: A Text Book of Agricultural Statistics. "New Age International Publishers, pp 281-309.

Raskin, I., 1992. Role of salicylic acid in plant. Ann. Rev. Plant Physio. Plant. Mol. Bio. 43: 439-463.

Samiullah, S.A., M.M. Ansori and R.K. Afridi, 1988. B- vitamin in relation to crop productivity Indian, Rev. Life SCL $8: 51-74$.

Sayed- Heba, F.I., 2010. Effect of stimulant aminoquelant-Ca and Zinc on yield and berries quality of Thompson seedless grapevines M. Sc. Thesis Fac. of Agric. Minia Univ. Egypt.

Seleem- Basma, M. and H.M. Abd El- Hameed, 2008. Effect of the stimulant aminoqualent Ca on yield and berries quality of Thompson seedless grapevines. Minia J. of Agric. Res. \& Develop. 28 (1):1321.

Uwakiem, M. Kh., 2011. Effect of some organic, bio and slow release $\mathrm{N}$ fertilizers as well as some antioxidants on vegetative growth, yield and berries quality of Thompson seedless grapevines. $\mathrm{Ph}$. D, Thesis. Fac. of Agric. Minia Univ. Egypt. 
Vianello, A. and F. Marci, 1991. Generation of superoxide anion and hydrogen peroxide at the surface of plant cells. J. Bioenergetcs and Biomembranse. 23(2):409-423. 